\title{
Experimental Evidence on the Impact of Payments and Property Rights on Forest User Decisions
}

\section{OPEN ACCESS}

Edited by:

Christoph F. J. Meyer, University of Salford, United Kingdom

Reviewed by:

Meine van Noordwijk,

World Agroforestry Centre

(ICRAF), Indonesia

Jorge C. Llopis,

University of Bern, Switzerland

Sarah Tolbert,

University of Wisconsin-Madison,

United States

*Correspondence:

O. Sarobidy Rakotonarivo sarobidy.rakotonarivo@gmail.com

Specialty section:

This article was submitted to Global Biodiversity Threats,

a section of the journa

Frontiers in Conservation Science

Received: 31 January 2021 Accepted: 28 June 2021 Published: 16 July 2021

Citation:

Rakotonarivo OS, Bell A, Dillon B

Duthie $A B$, Kipchumba $A$, Rasolofoson RA, Razafimanahaka J and Bunnefeld N (2021) Experimental Evidence on the Impact of Payments and Property Rights on Forest User

Decisions.

Front. Conserv. Sci. 2:661987. doi: 10.3389/fcosc.2021.661987

\section{O. Sarobidy Rakotonarivo ${ }^{1,2 *}$, Andrew Bell ${ }^{3}$, Brian Dillon ${ }^{4}$, A. Bradley Duthie ${ }^{1}$, Adams Kipchumba ${ }^{1}$, Ranaivo Andriarilala Rasolofoson ${ }^{5,6}$, Julie Razafimanahaka ${ }^{7}$ and Nils Bunnefeld ${ }^{1}$}

${ }^{1}$ Biological and Environmental Sciences, University of Stirling, Stirling, United Kingdom, ${ }^{2}$ École Supérieure des Sciences Agronomiques, Université d'Antananarivo, Antananarivo, Madagascar, ${ }^{3}$ Department of Environmental Studies, New York University, New York City, NY, United States, ${ }^{4}$ Dyson School of Applied Economics and Management 463 Warren Hall, Cornell University, Ithaca, NY, United States, ${ }^{5}$ Department of Population Medicine and Diagnostic Sciences, Cornell University, Ithaca, NY, United States, ${ }^{6}$ Gund Institute for Environment, University of Vermont, Burlington, VT, United States, ${ }^{7}$ Madagasikara Voakajy, Antananarivo, Madagascar

Clearing forests for swidden agriculture, despite providing food to millions of farmers in the tropics, can be a major driver of deforestation. Payments for ecosystem services schemes can help stop swidden agriculture-induced forest loss by rewarding forest users for maintaining forests. Clear and secure property rights are a key prerequisite for the success of these payment schemes. In this study, we use a novel iterative and dynamic game in Madagascar and Kenya to examine farmer responses to individual and communal rights to forestlands, with and without financial incentives, in the context of swidden agricultural landscapes. We find that farmer pro conservation behaviour, defined by the propensity to keep forests or fallows on their lands, as well as the effects of land tenure and conservation incentive treatments on such behaviour, differ across the two contexts. The average percentages of land left forest/fallow in the game are 65 and $35 \%$ in Kenya and Madagascar, respectively. Individual ownership significantly improves decisions to preserve forests or leave land fallow in Madagascar but has no significant effect in Kenya. Also, the effect of the individual tenure treatment varies across education and wealth levels in Madagascar. Subsidy increases farmers' willingness to support conservation interests in both countries, but its effect is four times greater in Kenya. We find no interaction effects of the two treatments in either country. We conclude that the effectiveness of financial incentives for conservation and tenure reform in preserving forestland vary significantly across contexts. We show how interactive games can help develop a more targeted and practical approach to environmental policy.

Keywords: interactive game, swidden agriculture, payments for ecosystem services, property rights, forest land tenure, forest conservation, Madagascar, Kenya

\section{INTRODUCTION}

Nature conservation is coming increasingly into conflict with human livelihoods (Redpath et al., 2013). In the tropics, large forest areas are being converted to agriculture by shifting cultivation, also known as swidden agriculture (Fox et al., 2000). While other macro-economic or distant factors such as migration and remote market demand can cause forest loss (Meyfroidt et al., 2013; Cairns, 2015), swidden agriculture has long been considered a major driver of deforestation and 
biodiversity loss (Zabel et al., 2019). However, swidden agriculture provides subsistence for millions of people across the developing world (Van Vliet et al., 2012) and covers roughly 280 million hectares worldwide, including both cultivated fields and fallows (Heinimann et al., 2017). Market-based economic instruments such as payments for ecosystem services (PES) schemes offer potential for reducing swidden agriculture-induced forest loss while improving local people's livelihoods (Namirembe et al., 2014; Wunder, 2015). PES programmes are based on rewarding forest users for maintaining or increasing the provision of ecosystem services (Noordwijk et al., 2012).

Clear and secure property rights are a key prerequisite for the success of PES schemes, as they determine who is eligible to benefit and how contracts can be legally enforced (Swallow and Meinzen-Dick, 2009; Corbera et al., 2020). In many tropical countries, governments have de jure ownership of forestlands (Kelly and Peluso, 2015). However, state ownership is often weakly enforced in practise or is locally contested (Unruh, 2008; Rakotonarivo et al., 2018). While much can be learned from reviews on the importance of various contextual, design, and implementation features on the effectiveness of PES schemes (e.g., Börner et al., 2017; Snilsveit et al., 2019; Wunder et al., 2020), evidence is missing for how the effectiveness of PES in incentivising pro-conservation behaviour might vary between land tenure systems such as communal and individual ownership of forestlands. Yet, pilot or real-world interventions to address this knowledge gap would be difficult to implement because of practical costs and ethical concerns. In this study, we develop a novel interactive and dynamic game to investigate the effects of payments and different types of property rights on forest-user behaviour in the context of swidden agricultural landscapes in Madagascar and Kenya.

Games can extend more traditional survey approaches by testing the impact of policy interventions that may not yet have analogues in past experience and would be difficult or expensive to test in reality (Redpath et al., 2018). This is the case in many African contexts where well-defined forest tenure regimes such as individual and communal forest ownership are largely missing, and where forest tenure is contested and unclear, and forest users are not landowners (Rights and Resources Initiative, 2018; Sunderlin et al., 2018; Miller et al., 2021). While we were not able to include such de facto contested tenure situations in our experimental game design, our study examined the influence of individual and communal property rights to forestlands on forest user behaviour and thus, provides valuable insights on the influence of potential tenure reform policies on conservation outcomes. In addition, experimental games allowed us to vary property rights regimes exogenously while holding other factors constant, which is challenging in observational, quasi-experimental studies.

Games have been used to study individual or group coordination strategies and facilitate change processes and social learning in complex socio-ecological contexts (e.g., Bodonirina et al., 2018; Celio et al., 2019; Speelman et al., 2019; Andreotti et al., 2020; Garcia-Barrios et al., 2020). In other settings, games have been used to investigate the effectiveness of alternative payment structures in encouraging pro-conservation behaviour in the context of forest resources (e.g., Travers et al., 2011; Narloch et al., 2012; Kaczan et al., 2017; Salk et al., 2017; Andersson et al., 2018; Gatiso et al., 2018). These studies are useful for exploring how conservation incentives are best delivered (e.g., to groups or individuals), but they offer limited insights into the potential impacts of communal or individual ownership over forestlands on farmer behaviour. The traditional pen and paper approach used in most of these games also limits their potential to model ecologically relevant temporal and spatial dynamics of the resources, particularly at the landscape level (Janssen et al., 2014). This might limit their ability to attribute the observed behavioural patterns to the experimental interventions (Cardenas et al., 2009).

We used a novel game to test how alternative policy interventions affect farmer pro-conservation behaviour. We conducted the games in Madagascar and Kenya, two countries which have varying degrees of reliance on swidden agriculture as described in the study context section. The Netlogo framework (Wilensky, 1999) allowed us to include both temporal and spatial dynamics in the games, which significantly increased realism and famers' engagement (Rakotonarivo et al., 2021a,b). We specifically aimed to address the following questions: (i) How do communal or individual rights affect farmer decisions to farm or keep forests or fallows in the games? (ii) Do financial incentives affect rural farmers' willingness to keep forests or fallows? (iii) Do the effects of the tenure and financial incentive treatments vary across different wealth, education and community trust levels? (iv) How do treatment effects vary across the two contexts, Madagascar and Kenya?

\section{MATERIALS AND METHODS Game Design}

The game-Sharedspace-was framed around farmer decisions in swidden agricultural landscape and played on tablet computers linked via a mobile hotspot. It is part of a family of games developed using the NetLogo modelling platform to examine conflicts among people, resources, and wildlife that includes NonCropShare, a coordination game for insect-based ecosystem services (Bell et al., 2016), and GooseBump, a coordination game for resolution to human-wildlife and conservation conflicts (Rakotonarivo et al., 2021a,b). In the game, four farmers make land use decisions on a $6 \times 6$ grid-cell digital farming landscape. Each participant has an equal share of the land in the game, a total of nine cells each. On each cell, the farmer can decide to (i) conserve the forest (or fallow) or (ii) farm it for their private benefits (Figures 1, 2). Each interactive game session consists of 7-12 rounds analogous to agricultural years where participants make decisions and have the option to communicate with other players between game sessions about any aspects of the game, including their choices, and beliefs about the optimal strategy. The number of rounds was randomised to prevent participants from anticipating the conclusion of a game session. In each round, participants decide whether to farm the cells or keep them as forest or fallow. Each grid cell was framed as "forest" at the 


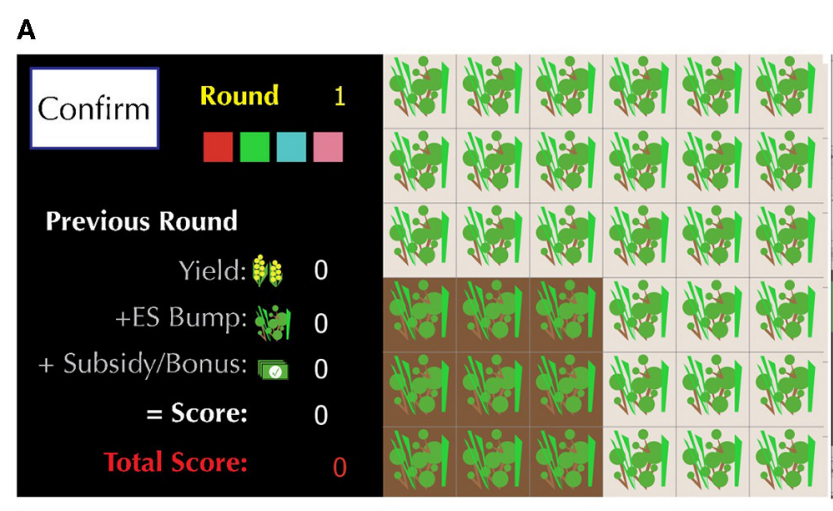

C

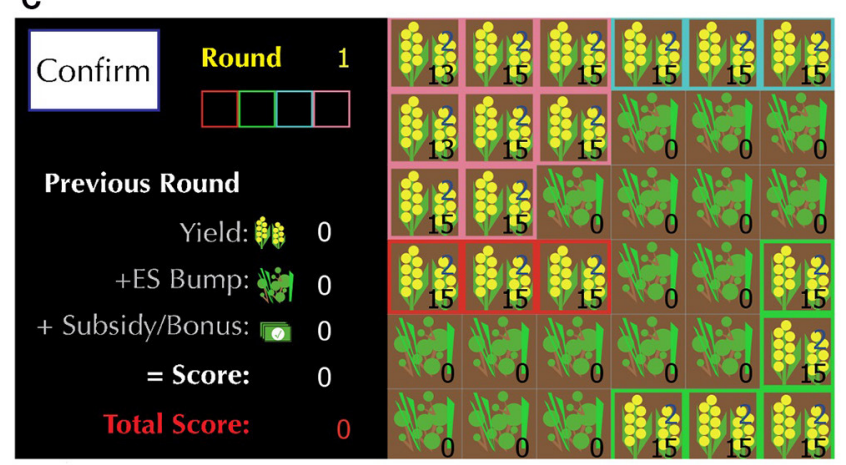

B

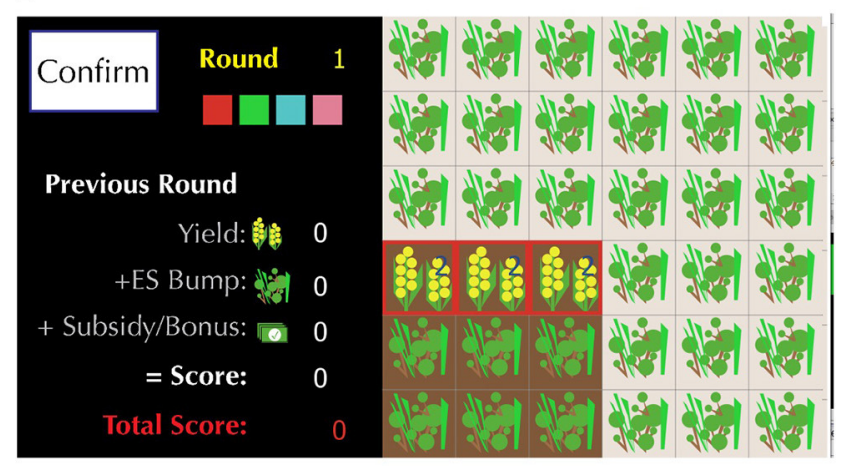

D

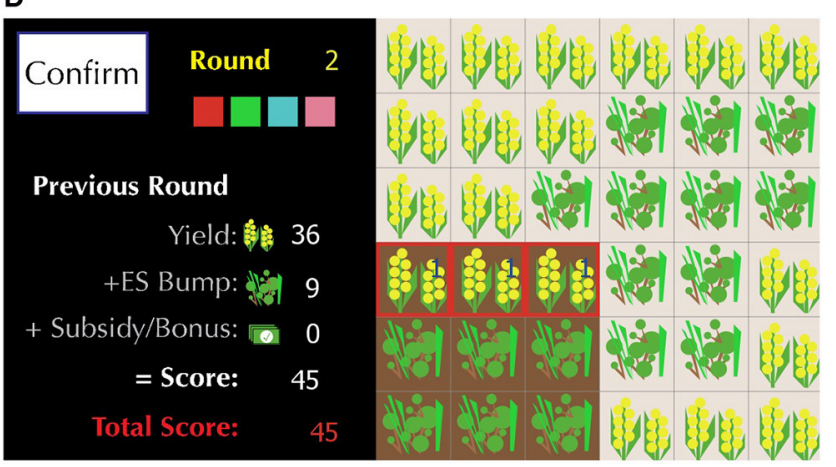

FIGURE 1 | Visual repress entation of the farming landscape in the individual right treatments, players are colour-coded, (A) the bottom left corner is the active player's $3 \times 3$ grid at the start of round $1 ;$ (B) the active player farmed three cells (the red coloured cells), the black numbers in the red coloured cells are the remaining number of farming cycles with high yield; (C) Game screen of the active player after all four players have made decisions at the end of round 1, the decisions taken by the other players are also visible (the green, blue, and pink cells are farmed by the three other players); (D) game screen of the active player at the start of round 2, the scores of the active player in previous round is shown in the left-hand side of the panel.

start of each game and "fallow" once it has been farmed for the first time.

Farming the cell brings some yields, while keeping the forest or fallowing the cell boosts crop yields to neighbouring farmed cells through ecosystem service provision (e.g., pollination, soil restoration, watershed protection, landslide prevention) (Table 1). To reflect this, a forest/fallow cell increases the yield of all farmed cells within a radius of two cells by 1 . These effects can spill over from one farmer to another. Since a fallow land yields the same ecosystem services as a fully intact forest, they were referred to as forest/fallow hereafter.

Returns from farming depend on the conditions of the lands. Farming gives a payoff of 12 when the farmed land is in good condition and 10 when it is not. If participants farm the same forest/fallow cell for two consecutive rounds, the land becomes depleted and the yield drops to the lower level in the following round. If participants continue farming the land of lower quality, the yield remains at the lower level. Fallowing the land for at least two consecutive rounds returns the yield to the higher level, and the soil fertility is restored (Table 1). The game is therefore temporally and spatially dynamic; the state of a cell in any given round is dependent on decisions taken in previous rounds, and the ecosystem's service provision depends on concurrent decisions on nearby cells. The maximum output for a farmed square from ecosystem services benefits is capped at 15 for a good quality land and 12 for a low-quality land. At the start of each session, all land is in good condition and leads to a high yield if farmed (Table 1).

In some of the treatments, a subsidy of $x$ is given for every cell of forest/fallow in the landscape, where $x x$ randomly takes aon random value of 4,8 , or 12 with equal probability in a game. Summing across squares under their control, participants' overall scores are calculated in each round as,

$$
\text { Score }=\Sigma_{\mathrm{n}=1}^{9} \text { Yield }+\Sigma_{\mathrm{n}=1}^{9} \text { Ecosystem services }+\Sigma_{\mathrm{n}=1}^{9} \text { Subsidy }
$$

To ensure sufficient realism and motivation for play, our treatments incorporated spatial dynamics (ecosystem services spilling over from forest or fallow lands to neighbouring farms). We also allow for the decisions of current rounds to potentially affect payoffs in future rounds. These game dynamics make it impossible to find closed form solutions for optimal play. However, it is possible to derive analytical solutions for simplified conditions (e.g., a single round of game play). The game parameters (Table 1) were specified to reflect a plausible range 


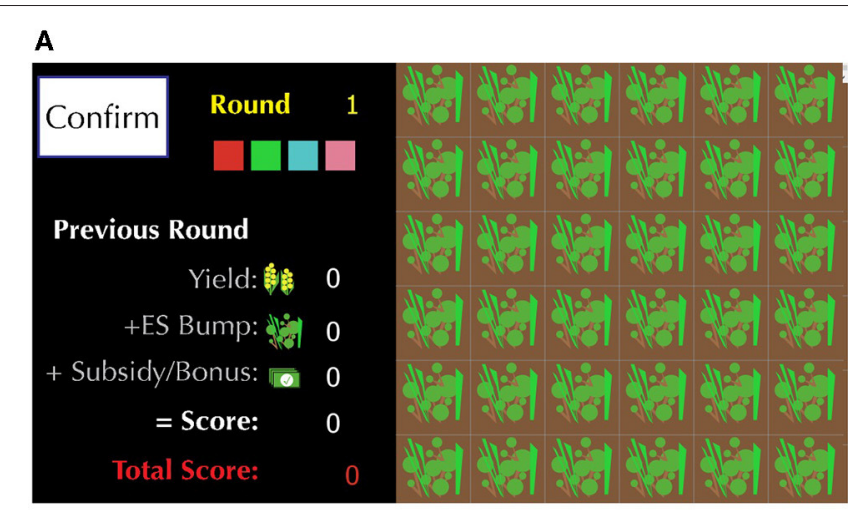

C

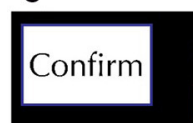

\section{Round 1}

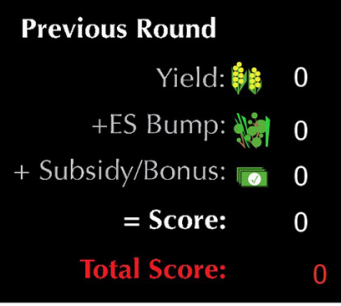

B

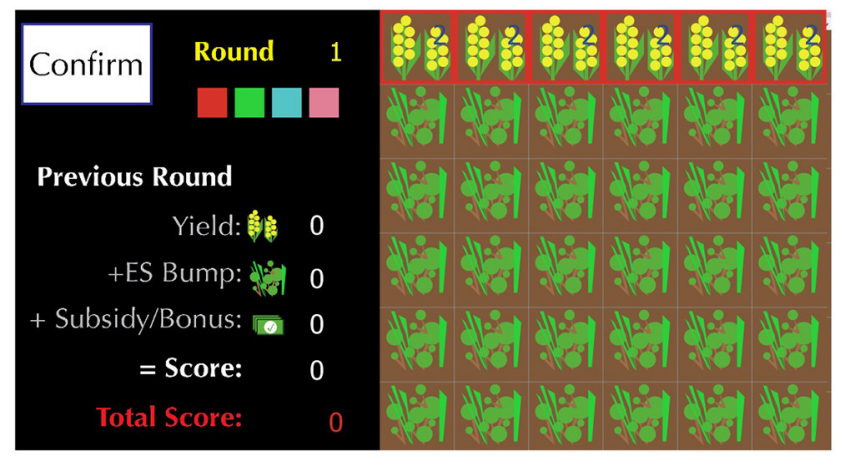

D

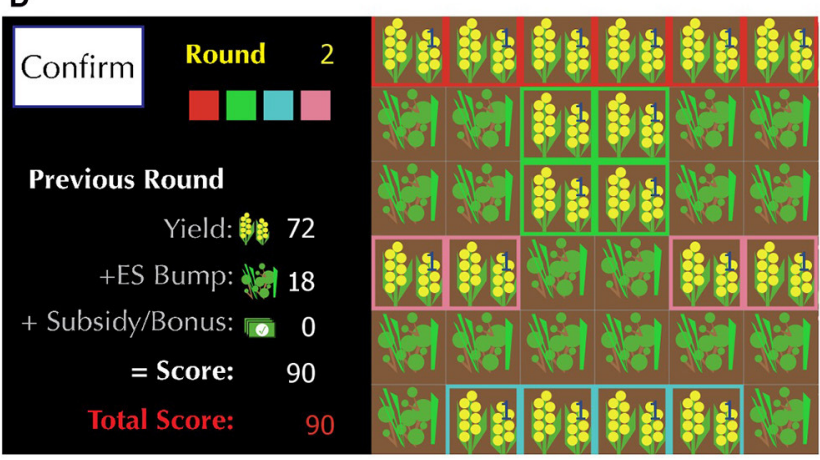

FIGURE 2 | Visual representation of the farming landscape in the common right treatments, players are colour coded, (A) game screen of the active player at the start of the game; the player can farm any cells in the landscape (up to nine); (B) the active player farmed six cells (the red coloured cells in the first row of the grid); (C) game screen of the active player after all four players have made decisions at the end of round 1, the decisions taken by the other players are also visible, the green, blue and pink cells are farmed by the three other players; (D) game screen of the active player at the start of round 2 , the scores of the active player in previous round is shown in the left-hand side of the panel.

TABLE 1 | Game parameters.

\begin{tabular}{|c|c|c|c|}
\hline & \multicolumn{3}{|c|}{ Player choice (cell level) } \\
\hline & \multirow[t]{2}{*}{ Forest or Fallow } & \multicolumn{2}{|c|}{ Farm } \\
\hline & & High yield* & Low yield ${ }^{\star \star}$ \\
\hline Yield & 0 & 12 & 10 \\
\hline Neighbourhood effect & 0 & $\begin{array}{c}+1 \text { for all neighbouring forest/forest/fallow } \\
\text { cells (in a radius of two cells around the } \\
\text { cell), up to } 15\end{array}$ & $\begin{array}{c}+1 \text { for all neighbouring forest/fallow cells } \\
\text { (in a radius of two cells around the cell), up } \\
\text { to } 12\end{array}$ \\
\hline Subsidy & $\times[4,8,12]^{\star \star \star}$ & None & None \\
\hline
\end{tabular}

*At the start of each session, the yield on all cells is at the high level if the land is farmed.

**Yield drops to the lower level in any given round if the cell is farmed in the two previous rounds. It recovers the higher level after two consecutive rounds of fallowing.

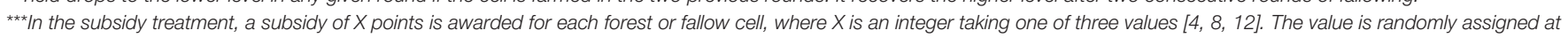
the start of each game session.

of potential costs and benefit scenarios under these simplified conditions (for instance, for a single game round, farming all landscape cells yields the highest payoff regardless of the decisions of other players; however, a cooperative strategy of fallowing a single cell can result in a total higher total payoff for players than if all players farm all of their cells, despite being vulnerable to defection from the higher payoff strategy of farming all cells). We have provided a detailed explanation of the theory underlying our game design in Appendix A in Supplementary Material. While such theoretical predictions 
were useful for calibrating the game parameters, our analyses do not aim to test specific game theoretic predictions, but instead focus on how farmers respond to policy interventions and how these responses vary across different sub-groups.

\section{Experimental Design and Data Collection}

We used a within-subject design; each game session consists of one practise session (3 rounds) followed by four different game treatments played in random order in each game session. The four game treatments form a $2 \times 2$ design of (i) Subsidy vs. no subsidy, (ii) individual vs. communal property rights. Communication between participants was permitted in all the sessions as this mirrors the condition in which real-life incentive schemes operate. All elements of the game were explained at the start, including the randomly drawn subsidy values. The participants were all sitting in a circle and could easily talk to each other. The fallowing history and high/low yield status were visible on screen and could be tracked by participants.

In the individual property rights treatments, each participant is endowed with nine forest patches at the start of each game (3 $\times 3$ grid-cell section of the $6 \times 6$ grid-cell agricultural landscape) (Figure 1). In each game round, participants choose whether or not to farm each cell. All four players make decisions in parallel every round. The round ends when all players have confirmed their choices. Participants can farm *or* forest/fallow cells as desired in all subsequent rounds. The scores (total points earned) are calculated for each cell on the choices made in and around the cell. At the end of each round, every participant can see decisions made by all participants in the landscape and what yields were achieved in each cell. When a subsidy is added, a randomly assigned flat subsidy is privately offered to each of the participant forest/fallow lands.

Under communal property rights, all four participants can access any cells in the agricultural landscape (Figure 2), this can mimic situations where farmers collectively own and manage forested lands. In each round, each participant can farm a maximum of nine cells, as in the individual rights treatment. In each game round, participants make simultaneous decisions, and the round ends when all four players have confirmed. Participants' identity is colour coded, so players can see each other's decisions during the round. A cell that is farmed by one participant can no longer be farmed by another participant (cells are allocated on a first come first serve basis during the round). Participants can choose to farm the same cells in subsequent rounds or move to other cells (in which case the cell becomes available to other players). When a subsidy is introduced, a randomly assigned flat subsidy is collectively offered for all forest/fallow lands at the landscape scale, the total value of the subsidy is then shared equally by all four participants.

We conducted our study in Madagascar and Kenya, two countries which have varying degrees of reliance on swidden agriculture (see section below on study context). We selected four villages near the Mangabe protected area in eastern Madagascar, and two villages adjacent to Mount Kenya National park and forest reserve in Kenya (Figure 3). We purposely selected villages near protected areas because of their specific features: participants in these settings live near protected forest resources; they have experiences of conservation restrictions, yet many of them are still highly dependent on swidden agriculture. These forest communities are also among the poorest in Madagascar and in Kenya.

In each of the study villages, we first compiled a full list of households residing in the village using key-informant interviews, ensuring isolated households and hamlets were also included. We then randomly sampled $75 \%$ from each list allowing for substitution if the selected household was not present in the villages at the time of the study or was not willing to participate. In total, we administered the games to 272 participants in Madagascar (68 groups of four participants) and 100 participants in Kenya (25 groups of four participants). Only one representative per household, the one who makes most agricultural decisions, was invited to participate in the games. Participants were compensated $\sim 1$ day of local labour wage (2.5 and 3.5 USD in Madagascar and Kenya, respectively) for their time, plus a performance bonus based on their game play, 0.25 USD per 75 points earned in one of the games drawn randomly at the end of the session; this bonus ranged from 0.5 to 2.5 USD. The entire process lasted 60 to $120 \mathrm{~min}$.

The game design and protocol (see Supplementary Material) were carefully piloted in nearby villages prior to implementation. We also conducted a follow-up survey with each participant after they had participated in the game. The survey included socio-economic characteristics such as age, gender, education, wealth levels, land holdings and community trust attitudes. After we finished administering the games in each village, we also facilitated a group debriefing session in which most participants attended. The aim of the debriefing was to explore respondents' rationales for their game decisions and relate their experiences from playing the games with their real-life experiences of forest conservation and farming practises. The research ethics committee of the University of Stirling approved this study; we told participants that results would be presented in aggregate form and would not be linked to their identity or villages. We gained verbal informed consent from all participants before implementing the games.

\section{Study Context}

Madagascar's protected areas have expanded from $3.1 \%$ of the terrestrial surface area (1.8 million hectares) in 2003 to $\sim 12 \%$ by 2010 (Corson, 2014; Gardner et al., 2018). Despite this expansion, deforestation continues at an alarming rate (Vieilledent et al., 2018) and is driven primarily by swidden agriculture (Urech et al., 2015; Zaehringer et al., 2015). The vast majority of local communities still rely on swidden agriculture to sustain their livelihoods (idem) and transitions to more intensive or sustainable agricultural practises throughout the island are yet to happen (Scales, 2014; Llopis et al., 2019).

In Kenya, as in many Sub-Saharan Africa countries, agriculture fuels the foundation of the economy and mostly consists of smallholder farmers (McCord et al., 2015). In Kenya, the traditional agricultural system based on swidden agriculture has become less common (Heinimann et al., 2017) and has over the years been replaced by more intensive small-scale agriculture 


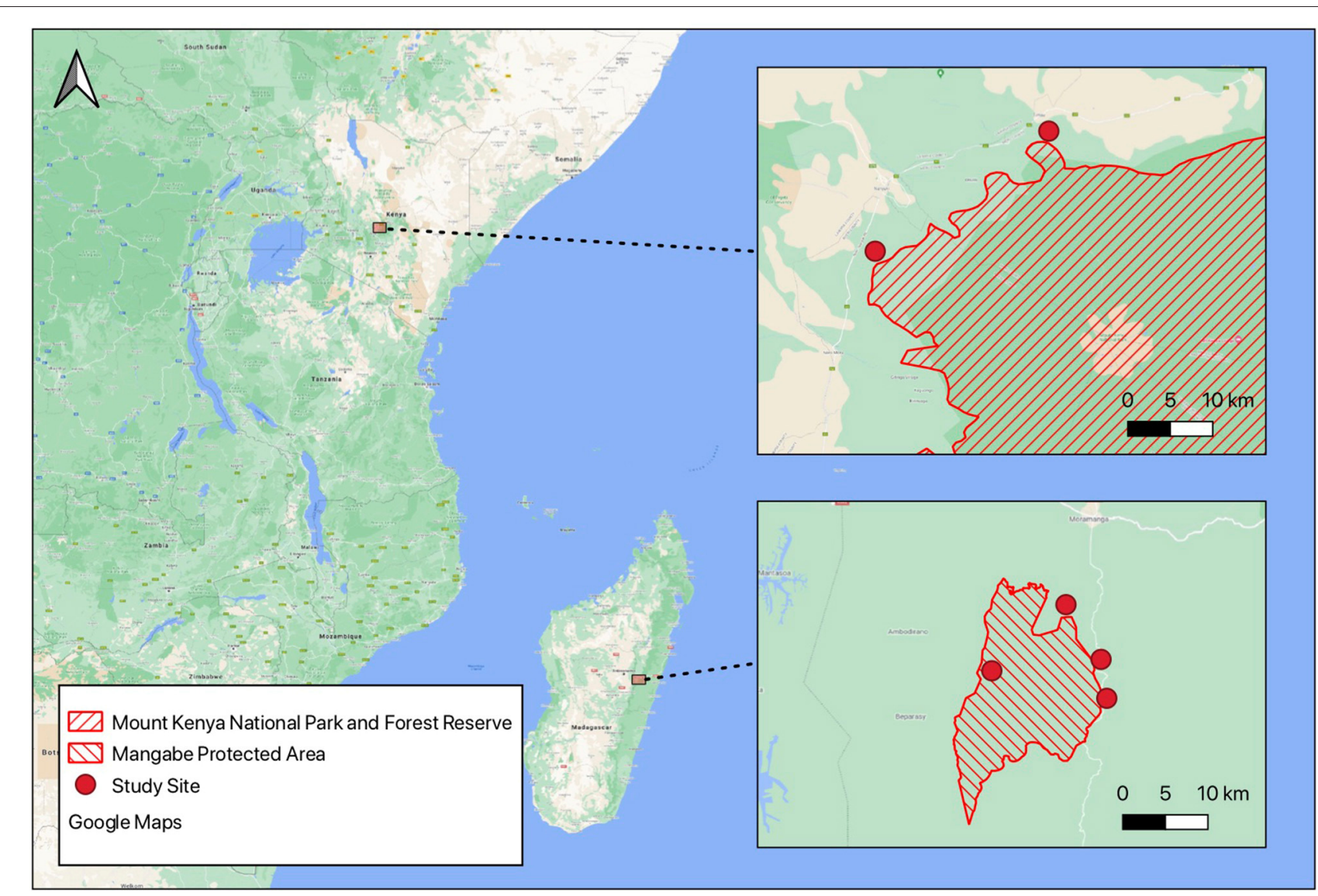

FIGURE 3 | Study sites (four villages near the Mangabe protected area in eastern Madagascar, and two villages adjacent to Mount Kenya National park in Kenya).

(Eckert et al., 2017). However, in the wake of population increase in Kenya, more land is put under cultivation to meet the food demand (Eckert et al., 2017). Forest conversion to agricultural lands (especially subsistence) in Sub-Saharan Africa is a popular practise, and Kenya is not exempted.

Decentralisation processes or the transfer of management rights to local communities were initiated in both Madagascar and Kenya in the 1990s and have led to the establishment of community-based forest management or forestry associations (Ferguson et al., 2014; Chomba et al., 2015). All participants surveyed in this study were members of such community associations. In theory, communities' rights in these associations are limited to management, only governments have a vested right to legally own forestlands in both countries. Therefore, the individual and communal property rights treatments investigated in this study (in which local people enjoy a full bundle of rights over forestlands, including ownership, exclusion and alienation rights) (Schlager and Ostrom, 1992) are hypothetical treatments. We explained to our study participants that in our game scenarios, they own the forestlands and have full freedom of choice over their use. We also emphasised our independence from government authorities and ran lengthy warm-up sessions to desensitise the issue of forest clearing for swidden agriculture and ensure participants fully understood the rules of the game.

\section{Data Analysis}

Our main outcome variable is the average percentage of cells left forest/fallow (average number of forest/fallow cells $\times 100 / 9$ ), defined at the individual player level. This variable represents game level data summed over the rounds within each game treatment. Rounds 9 to 12 were dropped to avoid end game effects. The dataset is panel in nature because the randomly assigned treatment varies across but not within games and individuals are observed at different points in time (as in a within-subject design). We estimate average treatment effects by regressing participant decisions to keep forests or fallow their lands on the treatment variables. The individual treatment is represented by a binary variable for whether or not participants have individual ownership of forestlands. For the subsidy treatment, the analysis considers both binary (whether or not a subsidy is given) and discrete random variables (subsidy rate per forest/fallow cell, taking the value of $0,4,8$, or 12 ).

We estimate a fixed effect panel data model on the pooled round-level data, separately for each country, and then test the significance of the estimated treatment effects on mean fallowing (or forested cells) (equation 2) (Woolridge, 2010). Fixed effect is a panel data model, which is useful when the outcome variable, mean fallowing, depends on explanatory variables, which are not observable but correlated with the observed explanatory variables 
(Woolridge, 2010). They thus allow the time-invariant observed and unobserved variables (i.e., variables that don't vary across treatments such as participants' demographics) to correlate with the error term. As data points from the same group are not independent from one another, we cluster the standard errors at the group-game level to allow for correlations between the group-specific error components. We also test for the interaction between individual rights and subsidy treatments.

$$
\begin{aligned}
& Y_{i t}=\lambda+a_{1} R_{i t}+a_{2} S_{i t}+a_{3} R_{i t} S_{i t}+\beta_{1} R_{i t} X_{i t}+\beta_{2} S_{i t} X_{i t} \\
& +\beta_{3} R_{i t} S_{i t} X_{i t}+\alpha_{i}+\varepsilon_{i t}
\end{aligned}
$$

$i$ : participant

$t$ : round

$Y$ : average percentage of cells left forest/fallow (outcome)

$\lambda$ : intercept

$R$ : property right (individual or communal)

S: subsidy

$X$ : participant characteristic (age, gender, education, wealth, land size, or community trust)

$a_{1}, a_{2}, a_{3}, \beta_{1}, \beta_{2}, \beta_{3}$ : scalar coefficients

$\alpha$ : fixed effects (unobserved time-invariant variables)

$\varepsilon$ : Time-varying error.

To assess how different subgroups might react to the treatments, we interact the two treatments with the specific variables of interest: education, wealth, and community interpersonal trust (this was specified as a three-way interaction between the two treatments, individual rights and subsidy and individual characteristics). Community trust is a numeric variable representing the weighted factor scores from three survey measures of trust among local communities (Table 2, Supplementary Figure 3). The wealth variable is the first principal component vector of a range of household wealth indicators (such as household assets, livestock, food security, extracted from a principal component analysis (PCA) using the psych package and promax rotation (Revelle, 2018) (Supplementary Table 1, Supplementary Figure 1). We hypothesised that subsidy would provide poorer participants with the much-needed short term resources to forego swidden agriculture (Nyein and Shinya, 2016; Dressler et al., 2017) and that higher educated participants would be more able to invest in off-farm activities and hence more likely to be responsive to financial incentives (by being less reliant on swidden agriculture and instead opting for more forest/fallow lands) (Van Vliet et al., 2013). We also expected that participants who have higher levels of trust toward other community members would be more likely to keep forest/fallow under communal ownership. This is because community members with increased interpersonal trust are more likely to comply with institutional arrangements for management of land and forests at the community level (Cramb et al., 2009). The controls include socio-economic variables such as age, gender, and lands under swidden agricultural systems.

All of the explanatory variables were standardised (expressed as z-scores), with the exception of the treatments and gender, to enable the comparison of magnitudes of estimated coefficients within models. We attempted to identify differences across the two countries and what factors might have contributed to those differences by comparing regression estimates across countries. The fixed effect models were conducted in STATA 16.0 and all other analyses (such as PCA) in R version 4.0.2 ( $\mathrm{R}$ Core Team, 2020).

\section{RESULTS}

\section{Participant Characteristics}

The control variables and the variables hypothesised to be associated with the treatment effects are summarised in Table 2. Significant differences are observed in the socio-economic characteristics of participants across the two countries. The average age of participants was 49 in Kenya and 35 in Madagascar. The number of official schooling years of the Kenya sample was three times higher than that of Madagascar (Table 2). Participants were $70 \%$ male in Madagascar, while gender was more balanced in Kenya ( $47 \%$ male). PCA of ten measures of wealth resulted in the first two principal components explaining $44 \%$ of the variation and revealed that the Kenya sample had much higher average wealth levels (Supplementary Table 1, Supplementary Figure 1). Participants in Kenya were much more food secure; they perceived that they had a variety of food and enough to eat for almost 12 months for the past year (vs. only 6 months in Madagascar) (Supplementary Table 1). The first axis of the PCA, which was used in the fixed effect model, was strongly correlated with measures of food security and livestock. Almost all the game participants relied on agriculture as their primary sources of income (98 and 100\% in Madagascar and Kenya, respectively). Twenty two percentage of the total sample in Kenya also had other sources of income such as livestock and small businesses vs. 55\% in Madagascar (such as small trades, charcoal making, wild food harvesting). Proxies for community trust were high (>53\%) in both countries (Supplementary Figure 3).

The average size of lands cultivated by each participant household was 0.39 and 0.97 hectares in Kenya and Madagascar, respectively. The lands cultivated by the Malagasy sample consisted mostly of swidden agriculture plots on hillsides, created originally from forest clearings. However, lands used by most Kenyan participants were under agroforestry practises, which consist of intercropping perennial and annual food crops, also known as the shamba system.

\section{Treatment Effects and Their Variations Across Subgroups}

Participants in Kenya kept significantly more forests/fallows on their lands (Figure 4, Supplementary Figure 2). The average percentage of forest/fallow lands across all rounds and games were 65 and 35\% in Kenya and Madagascar, respectively. Individual ownership significantly increased decisions to keep forest/fallow by 12 percentage points in Madagascar but had no significant effect in Kenya (models 1 and 2, Table 3). Subsidies also had slightly different effects on participant decisions in each of the two countries, significantly raising decisions to keep forest/fallow in Kenya by 9 percentage points and only by 2 percentage points in Madagascar. Decisions to keep forest/fallow did not significantly change across rounds. However, in Madagascar, decisions to fallow decreased with 
TABLE 2 | Descriptive statistics of predictor variables included in the models.

\begin{tabular}{|c|c|c|c|c|}
\hline Variables & Description & Country & \multicolumn{2}{|c|}{ Summaries } \\
\hline \multirow[t]{3}{*}{ Age } & Numeric variable indicating the age of the & Mean & 49.52 & 35.82 \\
\hline & participant & SD & 12.79 & 13.71 \\
\hline & & Min & 22 & 18 \\
\hline \multirow[t]{4}{*}{ Education } & Numeric variable indicating the years of official schooling of & Mean & 9 & 3.213 \\
\hline & the participant & SD & 2.543 & 3.049 \\
\hline & & Min & 0 & 0 \\
\hline & & Max & 15 & 12 \\
\hline Gender (Male) & Binary variable indicating whether the participant was male & $\%$ & $47 \%$ & $70 \%$ \\
\hline Wealth component 1 & Numeric variable representing the first principal component score from & Mean & -0.55 & 1.50 \\
\hline Off-farm income & $\begin{array}{l}\text { Binary variable indicating whether the participant household has other } \\
\text { sources of income than }\end{array}$ & $\%$ & $22 \%$ & $55 \%$ \\
\hline \multirow[t]{4}{*}{ Land size } & $\begin{array}{l}\text { Numeric variable measuring the land size cultivated by the household } \\
\text { agriculture }\end{array}$ & Mean & 0.97 & 2.41 \\
\hline & in the past agricultural year (measured in local units and converted in & SD & 0.86 & 4.61 \\
\hline & acres) - The value in Madagascar are proxies for areas used in swidden & Min & 0 & 0 \\
\hline & agriculture & Max & 5 & 27.1 \\
\hline \multirow[t]{4}{*}{ Community trust index } & Numeric variable representing the weighted factor scores from three & Mean & -0.003 & 0.010 \\
\hline & measures of trust among local communities; figure Sx; Cronbach's & SD & 0.97 & 0.75 \\
\hline & alpha $^{\star}=0.48$, the one-factor solution explained $48 \%$ of the total & Min & -2.22 & -2.5 \\
\hline & variance (this table and Supplementary Figure 3) & $\operatorname{Max}$ & 1.15 & 1.15 \\
\hline
\end{tabular}

rounds in three of the four treatment conditions (Figure 4). This effect was most pronounced under communal ownership; fallowing decisions were as high as $40 \%$ at the start of the game and decreased by half by round 3 (Figure 4). This was particularly the case when subsidy was also introduced under communal rights (Supplementary Figure 2). These results are robust to alternative specifications of subsidy as a continuous (models 2 and 4, Table 3) or categorical variable (Supplementary Table 3 ). We find no interaction effects of the two treatments in either country.

To examine how different subgroups react to the treatments and try to explain the differences in observed outcomes across the two different samples, we interacted the treatments with three variables of interest: education, wealth, and community interpersonal trust. Contrary to our expectations, we found no association between the effect of subsidy and wealth or education in either country (models 5 and 6, Table 3). These results persisted even when subsidy was specified as a continuous variable (models 7 and 8 , Table 3). Instead, we found that in Madagascar, education level and wealth affected the effectiveness of the individual property right treatments in encouraging fallowing decisions (Supplementary Figure 5). A one standard deviation increase in education is associated with an increase in fallowing of 3.3 percentage points under individual ownership: this amounts to almost $10 \%$ of the community ownership reference level. On the other hand, the individual right treatment was less likely to lead to increased decisions to keep forest/fallow among wealthier participants; a one standard deviation increase in wealth levels is associated with a decrease in fallowing of 1.6 percentage points under individual ownership (compared to communal rights) (model 5, Table 3). These effects were not robust to the alternative specification in which the subsidy is specified as a continuous variable (model 7, Table 3). Participants with larger swidden agriculture plots in Madagascar (as represented by the variable "land size", Table 2) were more likely to keep forest/fallow in the individual right treatments ( $2.3 \%$ increase which is robust to alternative specification) (model 5, Table 3).

We did not find any association between the property rights treatment and community trust level in either of the two countries. In Kenya, we did not observe any associations between the treatment effects and any of the socio-economic characteristics, except the off-farm income (model 8, Table 3 where subsidy was specified as a continuous variable). The subsidy was more effective at encouraging decisions to keep forest/fallow among participants who had other sources of income than agriculture (1.26\% increase). 


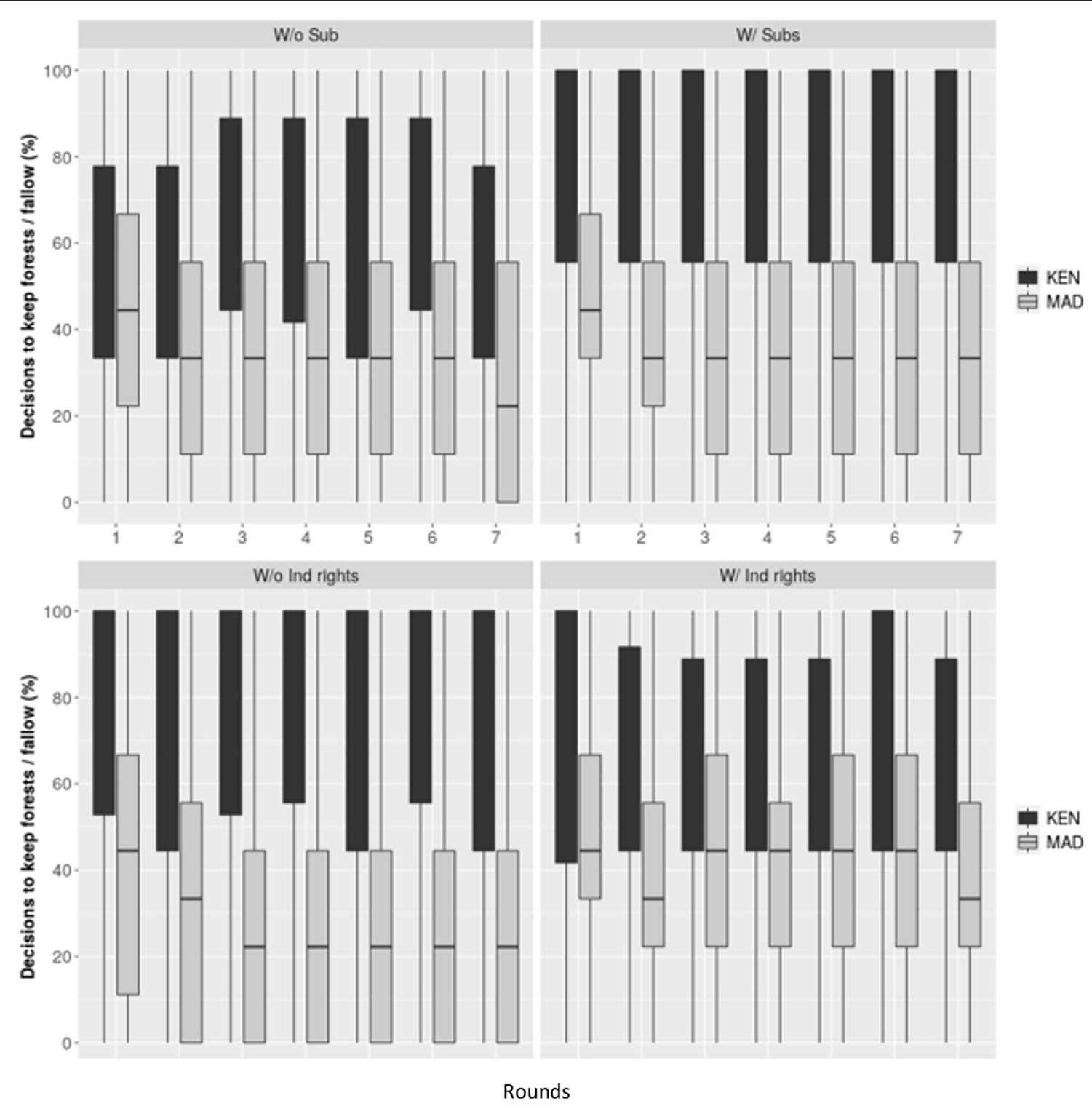

FIGURE 4 | Distribution of mean observed percentages of decisions to keep forest/fallow in the treatments and rounds (Subsidy takes a value of 1 if there is subsidy, 0 otherwise, and same with individual rights) across households and groups. The median marks the midpoint of the data and is shown by the line that divides the box into two parts. The box represents the middle $50 \%$ of percentages of decisions to keep forest/fallow.

\section{DISCUSSION}

Our study examines farmer responses to financial incentives and property rights to forestlands using a temporally and spatially dynamic interactive game in Madagascar and Kenya. We find that farmer proconservation behaviour (which we define as farmer propensity to keep forest or fallow lands) as well as the effects of land tenure and fallowing subsidy treatment vary considerably across the two contexts. Participants in the Kenyan sample were twice as willing on average to forego farming on their lands as players in the Malagasy sample. Though our experiment was not designed to fully disentangle the differences in game outcomes across the two countries, we discuss a few possible causes using responses to the follow up survey and insights from the literature and the community debriefings.

The first set of possibilities lie in the stark contrasts in wealth and swidden agricultural practises across the two countries. In Kenya, agroforestry practises have been partially shaped by a government-led plantation establishment and livelihood improvement scheme (PELIS). This scheme has been highly effective in improving food security and income among community members (Witcomb and Dorward, 2009). Since these agroforestry systems are practised on forested plots which are generally very fertile, levels of surplus output and extra income tend to be relatively high (Kagombe and Gitonga, 2005). However, farmers in eastern Madagascar mostly 
TABLE 3 | Estimates from the fixed effect panel data model showing the effects of the treatments on individual participant decisions to keep forest/fallow and their variations across different subgroups.

\begin{tabular}{|c|c|c|c|c|c|c|c|c|}
\hline & \multicolumn{2}{|c|}{$\begin{array}{l}\text { Treatments only (subsidy } \\
\text { binary) }\end{array}$} & \multicolumn{2}{|c|}{$\begin{array}{l}\text { Treatments only (subsidy } \\
\text { continuous) }\end{array}$} & \multicolumn{2}{|c|}{$\begin{array}{l}\text { Treatments and other } \\
\text { covariates (subsidy } \\
\text { binary) }\end{array}$} & \multicolumn{2}{|c|}{$\begin{array}{l}\text { Treatments and other } \\
\text { covariates (subsidy } \\
\text { continuous) }\end{array}$} \\
\hline \multirow[t]{2}{*}{ Ind_Rights } & $12.255^{\star \star \star}$ & -4.032 & $12.483^{\star \star \star}$ & -5.214 & $11.251^{\star \star \star}$ & -2.983 & $11.284^{\star \star \star}$ & -4.977 \\
\hline & $(1.117)$ & $(2.806)$ & $(1.138)$ & $(2.53)$ & (2.019) & $(3.827)$ & $(1.78)$ & (3.66) \\
\hline \multirow[t]{2}{*}{ Ind_Rights*Subsidy } & 0.951 & 2.222 & 0.059 & 0.551 & -0.846 & -0.385 & -0.095 & 0.365 \\
\hline & $(1.04)$ & (3.233) & $(0.122)$ & $(0.342)$ & (3.076) & $(4.453)$ & $(0.325)$ & $(0.456)$ \\
\hline \multirow[t]{2}{*}{ Ind_Rights*Age } & & & & & -0.948 & 1.716 & -1.005 & 2.107 \\
\hline & & & & & $(0.911)$ & $(2.147)$ & $(1.026)$ & (1.999) \\
\hline SubsidyAge & & & & & 1.341 & -0.546 & $0.162^{*}$ & -0.023 \\
\hline Ind_Rights*Male & & & & & $(1.97)$ & $(3.37)$ & $(1.909)$ & $(3.45)$ \\
\hline \multirow[t]{2}{*}{ Subsidy* Male } & & & & & -2.83 & -2.861 & -0.308 & -0.576 \\
\hline & & & & & $(2.16)$ & $(4.052)$ & $(0.26)$ & $(0.543)$ \\
\hline \multirow[t]{2}{*}{ Ind_Rights*Subsidy* Male } & & & & & 0.423 & 8.002 & 0.117 & 1.041 \\
\hline & & & & & (2.733) & $(4.931)$ & $(0.319)$ & $(0.615)$ \\
\hline \multirow[t]{2}{*}{ Ind_Rights*Education } & & & & & $3.352^{\star \star \star}$ & -0.216 & $3.143^{\star \star \star}$ & -0.007 \\
\hline & & & & & $(1.045)$ & $(2.106)$ & $(0.984)$ & $(1.839)$ \\
\hline \multirow[t]{2}{*}{ SubsidyEducation } & & & & & 0.811 & 0.742 & 0.067 & 0.102 \\
\hline & & & & & $(1.096)$ & $(1.316)$ & $(0.12)$ & $(0.192)$ \\
\hline Ind_RightsSubsidy ${ }^{*}$ Education & & & & & -0.078 & 2.044 & 0.047 & 0.152 \\
\hline \multirow[t]{2}{*}{ Ind_Rights*Land size } & & & & & $2.30^{\star \star \star}$ & -1.88 & $2.21^{\star \star \star}$ & -2.382 \\
\hline & & & & & $(0.751)$ & (2.749) & $(0.791)$ & (2.626) \\
\hline \multirow[t]{2}{*}{ Subsidy ${ }^{*}$ Land size } & & & & & 0.84 & 3.073 & 0.01 & 0.329 \\
\hline & & & & & $(1.193)$ & (2.045) & $(0.125)$ & $(0.2)$ \\
\hline \multirow[t]{2}{*}{ Ind_RightsSubsidy* Land size } & & & & & -1.407 & -1.204 & -0.139 & -0.109 \\
\hline & & & & & $(0.98)$ & (3.102) & $(0.110)$ & $(0.321)$ \\
\hline Ind_Rights*Community trust & & & & & 0.545 & -2.871 & 0.453 & -3.009 \\
\hline & & & & & $(0.832)$ & $(3.125)$ & $(0.843)$ & $(2.857)$ \\
\hline Subsidy ${ }^{*}$ Community trust & & & & & 0.876 & -2.57 & 0.106 & -0.234 \\
\hline & & & & & $(0.823)$ & $(1.581)$ & $(0.091)$ & $(0.223)$ \\
\hline Ind_Rights*Subsidy*Com-munity & & & & & -1.109 & 3.554 & -0.114 & 0.505 \\
\hline & & & & & $(1.071)$ & (2.335) & $(0.117)$ & $(0.305)$ \\
\hline Ind_Rights ${ }^{\star}$ Off farm_income & & & & & -1.582 & 0.91 & -0.973 & 2.595 \\
\hline & & & & & (1.956) & (5.222) & (1.954) & $(4.871)$ \\
\hline
\end{tabular}




\begin{tabular}{|c|c|c|c|c|c|c|c|c|}
\hline & \multicolumn{2}{|c|}{$\begin{array}{c}\text { Treatments only (subsidy } \\
\text { binary) }\end{array}$} & \multicolumn{2}{|c|}{$\begin{array}{l}\text { Treatments only (subsidy } \\
\text { continuous) }\end{array}$} & \multicolumn{2}{|c|}{$\begin{array}{l}\text { Treatments and other } \\
\text { covariates (subsidy } \\
\text { binary) }\end{array}$} & \multicolumn{2}{|c|}{$\begin{array}{l}\text { Treatments and other } \\
\text { covariates (subsidy } \\
\text { continuous) }\end{array}$} \\
\hline \multirow[t]{2}{*}{ Subsidy*Off farm income } & & & & & -1.331 & 5.168 & -0.068 & $1.268^{\star \star}$ \\
\hline & & & & & (2.044) & $(5.352)$ & $(0.211)$ & $(0.606)$ \\
\hline & & & & & (2.384) & (6.433) & $(0.271)$ & $(0.714)$ \\
\hline Mean (ind_rights =0) & 29.09 & 67.15 & 29.09 & 67.15 & 29.09 & 67.15 & 29.09 & 67.15 \\
\hline Mean (Subsidy = 0) & 33.95 & 60.52 & 33.95 & 60.52 & 33.95 & 60.52 & 33.95 & 60.52 \\
\hline R-squared & 0.341 & 0.187 & 0.342 & 0.187 & 0.38 & 0.209 & 0.379 & 0.244 \\
\hline
\end{tabular}

Subsidy is modelled both as a binary variable (models 1, 2, 5, and 6) and as a continuous variable (models 3, 4, 7, and 8). The treatments are the only explanatory variables in models 1, 2 , 3 , and 4 , while the treatments and other treatment-fixed variables are included in models 5, 6, 7, and 8 in interaction terms. Data were pooled across rounds within each game treatment. Standard errors are in parentheses, ${ }^{* * *} p<0.01,{ }^{* *} p<0.05,{ }^{*} p<0.1$.

rely on swidden agriculture with very low use of agricultural inputs, chemical fertilisers and improved seed varieties (Harvey et al., 2014). Most Malagasy farmers receive little to no technical assistance in crop production and rely on rudimentary technological approaches (Styger et al., 2007). These differences in farming practises across the two contexts are reflected in their different wealth levels, with the Kenyan sample being better off both with respect to technological assets and food security (Supplementary Figure 1). However, we note that these wealth measures were only proxies of rural income and do not fully account for rural livelihoods and environmental income (Angelsen et al., 2014).

Differences in conservation enforcement levels might have also contributed to the differences in forest/fallow decisions in the games across the two contexts. In the follow-up survey, all the Kenyan participants unanimously reported that the risks of being fined would deter them from clearing forests for agriculture, vs. $80 \%$ of the Malagasy participants. Although clearing forests for swidden agriculture is banned in Madagascar, enforcement on the ground is often very weak, and corruption and non-compliance are salient features of forest conservation in many rural areas (Gore et al., 2016). In these contexts, clearing forestland for agriculture often gives farmers land rights (Angelsen, 1999; Rakotonarivo et al., 2017). More rapid forest clearance, as observed among the Malagasy sample, becomes an investment to the farmer and is a right establishment strategy.

The individual rights treatment had no effect on Kenya participants' decisions but led to better conservation outcomes compared to the communal right treatment in Madagascar. While community members in Madagascar are entitled to decide how forest resources can be used and the corresponding benefits shared, these benefits are often in practise very vulnerable to elite capture (Poudyal et al., 2016). These elite captures often result in participants being much less inclined to follow community conservation rules and engage in less sustainable agricultural practises. These fears of biassed benefits toward the better socially connected community members were reflected in the survey responses; $42 \%$ of the Malagasy sample reported having low and very low trust toward the leaders and decision-making members of community forestry associations (Supplementary Figure 4). Community leaders can play a critical role in aligning community members' practises with the provisions of community-level institutions (Corbera et al., 2020). If they are not trusted by a large share of community members, they might fail to nurture the collective actions and social norms that have been associated with enhanced forest conservation under communal rights (Ostrom and Hess, 2008).

The literature suggests mixed evidence on the impact of property rights on environmental outcomes. While a comparative study found that indigenous communities management significantly reduced deforestation and forest carbon emissions in Bolivia, Brazil and Colombia (Blackman and Veit, 2018), a metanalysis suggests that community management and land tenure security were not consistently associated with either less or more deforestation (Busch and Ferretti-Gallon, 2017). The evidence is even less clear on the effectiveness of PES under individual and communal rights to forests. PES resulted in positive environmental outcomes among individual forestowning households in Uganda (Jayachandran et al., 2017) and Costa Rica (Arriagada et al., 2012). PES can be equally effective when built upon communal tenure rights such as community based-forest management (Brouwer et al., 2011; Baylis et al., 2012). The absence of interaction effects between our two policy options might be explained by the large effect of the individual 
property rights and financial incentives on participants' decisions in Madagascar and in Kenya, respectively.

In-migration and the community inability to prevent forest clearance by migrants were also reported as a potential explanation for the lower pro-conservation behaviour observed in the communally owned treatment in Madagascar. The debriefing suggested that migrants move to the forest frontier mostly to access new lands. As new migrants increase the number of people sharing the return from the common resources, participants perceived that their rights were more secure under individual ownership. Individuals who belong to a cooperative do not also perceive a direct link between their personal contributions and benefits. Migrants, who are also often better educated, do not often recognise the legitimacy of communal management rights. This often results in less secure property rights that lead potential users to engage in conflicts so as to gain control over forestlands through clearance. These patterns have also been observed elsewhere in Madagascar (Jones et al., 2018).

Interestingly, we found that in Madagascar, the positive effect of the individual tenure treatment in encouraging proconservation behaviour was significantly greater among better educated and wealthier participants. This might pose risks for equity if the privatisation of forest resources mostly benefits the elites, or the power and resource holders (Benjaminsen et al., 2009). We also found that participants with larger swidden agriculture plots in Madagascar were more likely to keep forest/fallow in the individual right treatments. This is most likely because they can afford to rotate between various plots and keep more forests or fallow lands (Styger et al., 2007).

In Kenya, the absence of a significant effect of the property right treatment on participants' decisions to keep forest/fallow are puzzling, as we did not observe any associations between the treatment effects and the participants' characteristics. The results might stem from the irrelevance of tenure security among the Kenyan sample who exclusively use public gazetted lands under the control of the Kenyan forest services for a limited number of years, with no prospect of rights transfer to forest users. Unlike the Malagasy sample, participants in Kenya showed relatively high levels of trust both toward the community forest associations leaders and the Kenyan forest service (Supplementary Figure 4). The Kenya participants also felt that the current government forest strategy balances forest conservation and rural development, mostly through the PELIS scheme which allows community members to practise agroforestry in government-owned degraded lands. Participants also perceived additional livelihood benefits from these schemes, such as fuelwood and access to pasture. This was in stark contrast to farmers' perceptions of conservation organisations in Madagascar, whose restrictions on forest use and access were felt to have severely constrained local livelihoods (Supplementary Figure 4) (Gore et al., 2016).

The subsidy increased farmers' willingness to support conservation interests in both countries, but its effect was considerably greater in Kenya. These results are congruent with previous studies showing the role of payments in incentivising forest conservation (Cárdenas, 2017; Sims and Alix-Garcia,
2017). The differences in the effect sizes of subsidy across the two contexts are not immediately clear, as the two samples differ in many socio-economic factors, including land ownership, farm holding size, education, wealth levels, and levels of trust toward governments and conservation agencies, which may affect people's attitudes toward the payments. These results might also be explained by unobservable factors beyond what the surveys and experiments were able to capture. As participants received both the show-up fee and a second payout that was tied to their performance in the games, this might have introduced some real stakes that may be associated with varying wealth levels across the two countries.

Another explanation for the different findings across countries lies in possible differences in the administration of the games. This is unlikely, since we used the same game instructions, and all enumerators were trained by the same person (lead author). We cannot rule out potential differences in understanding the game rules across the two countries which could be associated with different education levels. The use of the same game protocol, practise rounds, and visual handouts should have helped reduce these confounding factors.

As in all game-based studies, the external validity of our results (the extent to which the game decisions reflect what participants would do in real life) is difficult to assess (Jackson, 2012). Our game did not allow more detailed incorporation of the complex socio-ecological context and the study of social interactions as is common in serious boardgame studies (e.g., Celio et al., 2019; Speelman et al., 2019; Andreotti et al., 2020). Adding more complexity would risk both the tractability of the analysis and player engagement. In addition, the game features, which are stylised representations of the swidden agricultural systems, might not match participants' characterisations of these elements. In particular, the communal and individual property rights tested in our game design are new in both contexts, i.e., none of the participants have directly experienced such tenure reforms (see study section). Contested and unclear property rights is an issue in many tropical forest countries (Rights and Resources Initiative, 2018; Robinson et al., 2018; Sunderlin et al., 2018). The experimental games we developed in this paper were thus useful in testing the effectiveness of such interventions, which would otherwise be very costly and difficult to test at reality scale.

Despite the hypothetical nature of these interventions, understanding of the game rules and the interventions was generally high across the two countries and was greatly enhanced by the practise rounds, and additional explanations provided by the facilitators (OSR and AK who are both native speakers of Madagascar and Kenya, respectively). Surveys confirmed that participants seriously thought of the consequences of their choices and took into account real-life contexts (such as immigration, elite capture, low trust toward community leaders as evidenced by the debriefings) in their game decisions. In addition, a follow up question asking participants about their main goal in the games further suggested that $185(68 \%)$ and 97 (97\%) participants in Madagascar and Kenya, respectively, aimed to maximise their utility by playing as in real life (Supplementary Figure 6). 
Although our game settings were necessarily simplified, they were perceived by most participants as a safe and useful decisionsupport tool to voice their preferences. The incorporation of the temporal and spatial dimension also enhanced realism and helped uncover nuances that are invisible to conventional tools such as questionnaire surveys (Murnighan and Wang, 2016). For instance, most participants alluded to the importance of ecosystem services provided by the forests and fallow lands in the debriefing meetings (such as microclimate and protection against soil erosion) and the influence that these ecosystem services had on their decisions.

The differences in forest/fallow decisions in the context of the games and in the real-life contexts across the two countries also show that the games can provide a lens into real world choices. Games are best understood as one perspective within a body of knowledge on forest user behaviour and how they are affected by factors of interest such as property rights or incentives, rather than having specific real-world patterns against which they must be validated (Camerer, 2015). Our results provide important insights on the influence of PES and communal and individual property rights on forest user decisions in contexts where forest tenure is unclear and contested. We draw upon the group debriefing and the follow-up survey to contextualise our results.

While we had to simplify the property right treatments in our experimental game design and were not able to include a baseline reference of weak and insecure tenure, our study sheds light on the influence of individual and communal property rights to forestlands in PES schemes. We argue that if PES programmes are developed in contexts of weak state enforcement and unclear rights to forests, their effectiveness might be seriously compromised (e.g., Robinson et al., 2014; Paudel et al., 2015; Riggs et al., 2016; Horning, 2018; Corbera et al., 2020). The majority of effective PES to date have been implemented in countries where the institutional framework is well-defined and where land is individually owned (Pagiola, 2008; Karsenty et al., 2014; Myers et al., 2018; Sunderlin et al., 2018). Designing PES in situations of weak institutions is challenging, yet these contexts are dominant features of biodiversity hotspots where threats to ecosystem services are the highest (Chomitz et al., 2007) and where conservation actions are viewed as most urgent (Mittermeier et al., 2011).

In conclusion, we used a dynamic interactive game framed around farmer land-use decisions to examine farmer responses to two new policy options, financial incentives under individual and communal forest ownership. We found that their effectiveness in preserving forestland varied across contexts; the individual right treatment had no effect on participant decisions in Kenya, but in Madagascar, it led to much better conservation outcomes than the communal rights treatment. The incentives increased farmers' willingness to support conservation interests in both countries, but its effect was four times greater in Kenya. Such mixed relationships between property rights and forest conservation outcomes have also been reported in other contexts (Robinson et al., 2014; Busch and FerrettiGallon, 2017; Blackman and Veit, 2018). In contexts such as Madagascar, with strong reliance on swidden agriculture and a de facto open access regime, giving local communities individual property rights to forestlands on its own might be effective at incentivising conservation. However, where people feel relatively secure about their rights, and where people have adapted to stronger enforcement and transitioned from swidden agricultural practises, tenure reforms might be inefficient. In these contexts, subsidies can play a major role in encouraging proconservation behaviour. There is no panacea; no single set of institutions generates better outcomes for the resource and for the users under all conditions. We show how interactive games can help develop a more targeted and practical approach to environmental policy in a given context.

\section{DATA AVAILABILITY STATEMENT}

The datasets presented in this study can be found in online repositories. The names of the repository/repositories and accession number(s) can be found at: https://reshare. ukdataservice.ac.uk/854068/.

\section{ETHICS STATEMENT}

The studies involving human participants were reviewed and approved by the ethical review committee of the University of Stirling (GUEP286). Written informed consent for participation was not required for this study in accordance with the national legislation and the institutional requirements.

\section{AUTHOR CONTRIBUTIONS}

$\mathrm{OSR}, \mathrm{AB}$, and $\mathrm{AD}$ conceived the ideas and designed the games. $\mathrm{OSR}, \mathrm{AB}, \mathrm{AD}$, JR, and $\mathrm{NB}$ provided important inputs on the research design. OSR and AK collected the data. OSR analysed the data with inputs from $\mathrm{BD}$ and RAR. OSR led the writing of the manuscript. All authors have contributed critically to the drafts and have given final approval for publication.

\section{FUNDING}

Funding for this study was provided by the European Research Council under the European Union's H2020/ERC Grant Agreement No. 679651 (ConFooBio) to NB, the Spark funding from the University of Stirling, and the UK Government's Foreign, Commonwealth \& Development Office and the International Development Research Centre, Ottawa, Canada (as part of the Forest for Climate and People project). The interactive game was derived from NonCropShare, which was produced with financial support from the CGIAR Research Program on Water, Land and Ecosystems (WLE) and the CGIAR Research Program on Policies, Institutions and Markets (PIM). AD was supported by a Leverhulme Trust Early Career Fellowship.

\section{ACKNOWLEDGMENTS}

We thank Rachel Norman and Neal Hockley for their comments on an early draft of the game design. We are also grateful 
to STAARS fellows and mentors for their guidance and mentorship under the STAARS fellowship programme. We also thank Josue Rakotoarisoa and Voahirana Randriamamonjy from Madagasikara Voakajy for their assistance with data collection and site identification, as well as our study participants.

\section{REFERENCES}

Andersson, K. P., Cook, N. J., Grillos, T., Lopez, M. C., Salk, C. F., Wright, G. D., et al. (2018). Experimental evidence on payments for forest commons conservation. Nat. Sustain. 1, 128-135. doi: 10.1038/s41893-018-0034-z

Andreotti, F., Speelman, E. N., Van Den Meersche, K., and Allinne, C. (2020). Combining participatory games and backcasting to support collective scenario evaluation: an action research approach for sustainable agroforestry landscape management. Sustain. Sci. 15, 1383-1399. doi: 10.1007/s11625-020-00829-3

Angelsen, A. (1999). Agricultural expansion and deforestation: modelling the impact of population, market forces and property rights. J. Dev. Econ. 58, 185-218. doi: 10.1016/S0304-3878(98)00108-4

Angelsen, A., Jagger, P., Babigumira, R., Belcher, B., Hogarth, N. J., Bauch, S., et al. (2014). Environmental income and rural livelihoods: a global-comparative analysis. World Dev. 64, S12-S28. doi: 10.1016/j.worlddev.2014.03.006

Arriagada, R. A., Ferraro, P. J., Sills, E. O., Pattanayak, S. K., and CorderoSancho, S. (2012). Do payments for environmental services affect forest cover? A farm-level evaluation from Costa Rica. Land Econ. 88, 382-399. doi: $10.3368 /$ le.88.2.382

Baylis, K., Honey-Rose,'S. J., and Rami'Rez, M. I. (2012). "Conserving forests: mandates, management or money?", in AERE 2012 Annual Meeting.

Bell, A., Zhang, W., and Nou, K. (2016). Pesticide use and cooperative management of natural enemy habitat in a framed field experiment. Agric. Syst. 143, 1-13. doi: 10.1016/j.agsy.2015.11.012

Benjaminsen, T. A., Holden, S., Lund, C., and Sjaastad, E. (2009). Formalisation of land rights: some empirical evidence from Mali, Niger and South Africa. Land Use Policy 26, 28-35. doi: 10.1016/j.landusepol.2008.07.003

Blackman, A., and Veit, P. (2018). Titled amazon indigenous communities cut forest carbon emissions. Ecol. Econ. 153, 56-67. doi: 10.1016/j.ecolecon.2018.06.016

Bodonirina, N., Reibelt, L. M., Stoudmann, N., Chamagne, J., Jones, T. G., Ravaka, A., et al. (2018). Approaching local perceptions of forest governance and livelihood challenges with companion modeling from a case study around Zahamena National Park, Madagascar. Forests 9:624. doi: 10.3390/f9100624

Börner, J., Baylis, K., Corbera, E., Ezzine-De-Blas, D., Honey-Rosés, J., Persson, U. M., et al. (2017). The effectiveness of payments for environmental services. World Dev. 96, 359-374. doi: 10.1016/j.worlddev.2017.03.020

Brouwer, R. O. Y., Tesfaye, A., and Pauw, P. (2011). Meta-analysis of institutional-economic factors explaining the environmental performance of payments for watershed services. Environ. Conserv. 38, 380-392. doi: $10.1017 /$ S0376892911000543

Busch, J., and Ferretti-Gallon, K. (2017). What drives deforestation and what stops it? A meta-analysis. Rev. Environ. Econ. Policy 11, 3-23. doi: $10.1093 /$ reep/rew013

Cairns, M. F. (ed.). (2015). Shifting Cultivation and Environmental Change. Indigenous People, Agriculture and Forest Conservation. Oxford: Routledge.

Camerer, C. F. (2015). The Promise and Success of Lab-field Generalizability in Experimental Economics: A Critical Reply to Levitt and List. Available online at: https://ssrn.com/abstract=1977749

Cardenas, J., Janssen, M., and Bousquet, F. (2009). "Dynamics of rules and resources: three new field experiments on water, forests and fisheries," in Handbook on Experimental Economics and the Environment, ed J. A. List (Cheltenham; Northampton, MA: Edward Elgar Publishing), 1-27.

Cárdenas, J. C. (2017). Cash incentives avert deforestation. Nat. Clim. Chang. 7, 688-689. doi: 10.1038/nclimate3397

Celio, E., Andriatsitohaina, R. N. N., and Zaehringer, J. G. (2019). A serious game to parameterize Bayesian networks: validation in a case study in northeastern Madagascar. Environ. Model. Softw. 122:104525. doi: 10.1016/j.envsoft.2019.104525

\section{SUPPLEMENTARY MATERIAL}

The Supplementary Material for this article can be found online at: https://www.frontiersin.org/articles/10.3389/fcosc. 2021.661987/full\#supplementary-material

Chomba, S. W., Nathan, I., Minang, P. A., and Sinclair, F. (2015). Illusions of empowerment? Questioning policy and practice of community forestry in Kenya. Ecol. Soc. 20:2. doi: 10.5751/ES-07741-200302

Chomitz, K. M., Buys, P., De Luca, G., Thomas, T. S., and Wertz-Kanounnikoff, S. (2007). At Loggerheads? Agricultural Expansion, Poverty Reduction, and Environment in the Tropical Forests. Washington, DC: World Bank.

Corbera, E., Costedoat, S., Ezzine-De-Blas, D., and Van Hecken, G. (2020). Troubled encounters: payments for ecosystem services in Chiapas, Mexico. Dev. Change 51, 167-195. doi: 10.1111/dech.12540

Corson, C. (2014). "Conservation politics in Madagascar. The expansion of protected areas," in Conservation and Environmental Management in Madagascar, ed I. R. Scales (London; New York, NY: Routledge), 193-215.

Cramb, R. A., Colfer, C. J. P., Dressler, W., Laungaramsri, P., Le, Q. T., Mulyoutami, E., et al. (2009). Swidden transformations and rural livelihoods in Southeast Asia. Hum. Ecol. 37, 323-346. doi: 10.1007/s10745-009-9241-6

Dressler, W. H., Wilson, D., Clendenning, J., Cramb, R., Keenan, R., Mahanty, S., et al. (2017). The impact of swidden decline on livelihoods and ecosystem services in Southeast Asia: a review of the evidence from 1990 to 2015. Ambio 46, 291-310. doi: 10.1007/s13280-016-0836-Z

Eckert, S., Kiteme, B., Njuguna, E., and Zaehringer, J. G. (2017). Agricultural expansion and intensification in the foothills of Mount Kenya: a landscape perspective. Remote Sens. 9:784. doi: 10.3390/rs9080784

Ferguson, B., Gardner, C. J., Andriamarovolonona, M. M., Healy, T., Muttenzer, F., Smith, S. M., et al. (2014). "Governing ancestral land in Madagascar: have policy reforms contributed to social justice?", in Governance for Justice and Environmental Sustainability: Lessons Across Natural Resource Sectors in SubSaharan Africa, eds M. Sowman and R. Wynberg (London: Routledge), 63-93.

Fox, J., Truong, D. M., Rambo, A. T., Tuyen, N. P., Cuc, L. T., and Leisz, S. (2000). Shifting cultivation: a new old paradigm for managing tropical forests. Bioscience 50, 521-528. doi: 10.1641/0006-3568(2000)050[0521:SCANOP]2.0.CO;2

Garcìa-Barrios, L., Rivera-N`Òez, T., Cruz-Morales, J., Urdapilleta-Carrasco, J., Castro-Salcido, E., Peòa-Azcona, I., et al. (2020). The Flow of Peasant Lives: a board game to simulate livelihood strategies and trajectories resulting from complex rural household decisions. Ecol. Soc. 25:48. doi: 10.5751/ES-11723-250448

Gardner, C. J., Nicoll, M. E., Birkinshaw, C., Harris, A., Lewis, R. E., Rakotomalala, D., et al. (2018). The rapid expansion of Madagascar's protected area system. Biol. Conserv. 220, 29-36. doi: 10.1016/j.biocon.2018.02.011

Gatiso, T. T., Vollan, B., Vimal, R., and Kühl, H. S. (2018). If possible, incentivize individuals not groups: evidence from lab-in-the-field experiments on forest conservation in Rural Uganda. Conserv. Lett. 11:e12387. doi: $10.1111 /$ conl.12387

Gore, M. L., Lute, M. L., Ratsimbazafy, J. H., and Rajaonson, A. (2016). Local perspectives on environmental insecurity and its influence on illegal biodiversity exploitation. PLoS ONE 11:e0150337. doi: 10.1371/journal.pone.0150337

Harvey, C. A., Rakotobe, Z. L., Rao, N. S., Dave, R., Razafimahatratra, H., Rabarijohn, R. H., et al. (2014). Extreme vulnerability of smallholder farmers to agricultural risks and climate change in Madagascar. Philos. Transac. R. Soc. B Biol. Sci. 369:20130089. doi: 10.1098/rstb. 2013.0089

Heinimann, A., Mertz, O., Frolking, S., Egelund Christensen, A., Hurni, K., Sedano, F., et al. (2017). A global view of shifting cultivation: recent, current, and future extent. PLoS ONE 12:e0184479. doi: 10.1371/journal.pone.0184479

Horning, N. R. (2018). "Why deforestation persists in Africa: actors, interests, and interest alignment," in The Politics of Deforestation in Africa: Madagascar, Tanzania, and Uganda, ed N. R. Horning (Cham: Springer International Publishing), 1-41. 
Jackson, C. (2012). Internal and external validity in experimental games: a social reality check. Eur. J. Dev. Res. 24, 71-88. doi: 10.1057/ejdr.2011.47

Janssen, M. A., Lee, A., and Waring, T. M. (2014). Experimental platforms for behavioral experiments on social-ecological systems. Ecol. Soc. 19:20. doi: 10.5751/ES-06895-190420

Jayachandran, S., De Laat, J., Lambin, E. F., Stanton, C. Y., Audy, R., and Thomas, N. E. (2017). Cash for carbon: a randomized trial of payments for ecosystem services to reduce deforestation. Science 357, 267-273. doi: 10.1126/science.aan0568

Jones, J. P. G., Mandimbiniaina, R., Kelly, R., Ranjatson, P., Rakotojoelina, B., Schreckenberg, K., et al. (2018). Human migration to the forest frontier: implications for land use change and conservation management. Geo Geogr. Environ. 5:e00050. doi: 10.1002/geo2.50

Kaczan, D., Pfaff, A., Rodriguez, L., and Shapiro-Garza, E. (2017). Increasing the impact of collective incentives in payments for ecosystem services. J. Environ. Econ. Manage. 86, 48-67. doi: 10.1016/j.jeem.2017.06.007

Kagombe, J. K., and Gitonga, J. (2005). Plantation Establishment in Kenya-The Shamba System Case Study. Nairobi: Kenya Forests Working Group.

Karsenty, A., Vogel, A., and Castell, F. (2014). "Carbon rights", REDD+ and payments for environmental services. Environ. Sci. Policy 35, 20-29. doi: 10.1016/j.envsci.2012.08.013

Kelly, A. B., and Peluso, N. L. (2015). Frontiers of commodification: state lands and their formalization. Soc. Nat. Resour. 28, 473-495. doi: 10.1080/08941920.2015.1014602

Llopis, J. C., Harimalala, P. C., Bär, R., Heinimann, A., Rabemananjara, Z. H., and Zaehringer, J. G. (2019). Effects of protected area establishment and cash crop price dynamics on land use transitions 1990-2017 in north-eastern Madagascar. J. Land Use Sci. 14, 52-80. doi: 10.1080/1747423X.2019.1625979

McCord, P. F., Cox, M., Schmitt-Harsh, M., and Evans, T. (2015). Crop diversification as a smallholder livelihood strategy within semi-arid agricultural systems near Mount Kenya. Land Use Policy 42, 738-750. doi: 10.1016/j.landusepol.2014.10.012

Meyfroidt, P., Lambin, E. F., Erb, K.-H., and Hertel, T. W. (2013). Globalization of land use: distant drivers of land change and geographic displacement of land use. Curr. Opin. Environ. Sustain. 5, 438-444. doi: 10.1016/j.cosust.2013.04.003

Miller, D. C., Rana, P., Nakamura, K., Irwin, S., Cheng, S. H., Ahlroth, S., and Perge, E. (2021). A global review of the impact of forest property rights interventions on poverty. Global Environ. Change 66:102218. doi: 10.1016/j.gloenvcha.2020.102218

Mittermeier, R. A., Turner, W. R., Larsen, F. W., Brooks, T. M., and Gascon, C. (2011). "Global biodiversity conservation: the critical role of hotspots," in Biodiversity Hotspots: Distribution and Protection of Conservation Priority Areas, eds F. E. Zachos and J. C. Habel (Berlin; Heidelberg: Springer Berlin Heidelberg), 3-22.

Murnighan, J. K., and Wang, L. (2016). The social world as an experimental game. Organ. Behav. Hum. Decis. Process. 136, 80-94. doi: $10.1016 /$ j.obhdp.2016.02.003

Myers, R., Larson, A. M., Ravikumar, A., Kowler, L. F., Yang, A., and Trench, T. (2018). Messiness of forest governance: how technical approaches suppress politics in REDD+ and conservation projects. Glob. Environ. Change 50, 314-324. doi: 10.1016/j.gloenvcha.2018.02.015

Namirembe, S., Leimona, B., Van Noordwijk, M., Bernard, F., and Bacwayo, K. E. (2014). Co-investment paradigms as alternatives to payments for treebased ecosystem services in Africa. Curr. Opin. Environ. Sustain. 6, 89-97. doi: 10.1016/j.cosust.2013.10.016

Narloch, U., Pascual, U., and Drucker, A. G. (2012). Collective action dynamics under external rewards: experimental insights from andean farming communities. World Dev. 40, 2096-2107. doi: 10.1016/j.worlddev.2012.03.014

Noordwijk, M. V., Leimona, B., Jindal, R., Villamor, G. B., Vardhan, M., Namirembe, S., et al. (2012). Payments for environmental services: evolution toward efficient and fair incentives for multifunctional landscapes. Annu. Rev. Environ. Resour. 37, 389-420. doi: 10.1146/annurev-environ-042511150526

Nyein, C., and Shinya, T. (2016). The transition away from swidden agriculture and trends in biomass accumulation in fallow forests case studies in the Southern Chin Hills of Myanmar. Mountain Res. Dev. 36, 320-331. doi: 10.1659/MRD-JOURNAL-D-14-00083.1
Ostrom, E., and Hess, C. (2008). "Private and common property rights," in The Encyclopedia of Law and Economics, eds B. Bouckaert and G. De Geest (Northampton, MA: Edward Elgar), 332-379.

Pagiola, S. (2008). Payments for environmental services in Costa Rica. Ecol. Econ. 65, 712-724. doi: 10.1016/j.ecolecon.2007.07.033

Paudel, N. S., Vedeld, P. O., and Khatri, D. B. (2015). Prospects and challenges of tenure and forest governance reform in the context of REDD+ initiatives in Nepal. For. Policy Econ. 52, 1-8. doi: 10.1016/j.forpol.2014.12.009

Poudyal, M., Ramamonjisoa, B. S., Hockley, N., Rakotonarivo, O. S., Gibbons, J. M., Mandimbiniaina, R., et al. (2016). Can REDD+ social safeguards reach the 'right' people? Lessons from Madagascar. Glob. Environ. Change 37, 31-42. doi: 10.1016/j.gloenvcha.2016.01.004

R Core Team (2020). R: A Language and Environment for Statistical Computing. R Foundation for Statistical Computing, Vienna, Austria. Available online at: http://www.R-project.org/

Rakotonarivo, O. S., Bredahl Jacobsen, J., Poudyal, M., Rasoamanana, A., and Hockley, N. (2018). Estimating welfare impacts where property rights are contested: methodological and policy implications. Land Use Policy 70, 71-83. doi: 10.1016/j.landusepol.2017.09.051

Rakotonarivo, O. S., Jacobsen, J. B., Larsen, H. O., Jones, J. P. G., Nielsen, M. R., Ramamonjisoa, B. S., et al. (2017). Qualitative and quantitative evidence on the true local welfare costs of forest conservation in madagascar: are discrete choice experiments a valid ex ante tool? World Dev. 94, 478-491. doi: 10.1016/j.worlddev.2017.02.009

Rakotonarivo, O. S., Jones, I. L., Bell, A., Duthie, A. B., Cusack, J., Minderman, J., et al. (2021a). Experimental evidence for conservation conflict interventions: the importance of financial payments, community trust and equity attitudes. People Nat. 3, 162-175. doi: 10.1002/pan3.10155

Rakotonarivo, S. O., Bell, A. R., Abernethy, K., Minderman, J., Duthie, A. B., Redpath, S., et al. (2021b). The role of incentive-based instruments and social equity in conservation conflict interventions. Ecol. Soc. 26:8. doi: 10.5751/ES-12306-260208

Redpath, S. M., Keane, A., Andrén, H., Baynham-Herd, Z., Bunnefeld, N., Duthie, A. B., et al. (2018). Games as tools to address conservation conflicts. Trends Ecol. Evol. 33, 415-426. doi: 10.1016/j.tree.2018.03.005

Redpath, S. M., Young, J., Evely, A., Adams, W. M., Sutherland, W. J., Whitehouse, A., et al. (2013). Understanding and managing conservation conflicts. Trends Ecol. Evol. 28, 100-109. doi: 10.1016/j.tree.2012.08.021

Revelle, W. (2018). psych: Procedures for Personality and Psychological Research. Northwestern University, Evanston, IL. Available online at: https://CRAN.Rproject.org $/$ package $=$ psychVersion $=1.8 .12$

Riggs, R. A., Sayer, J., Margules, C., Boedhihartono, A. K., Langston, J. D., and Sutanto, H. (2016). Forest tenure and conflict in Indonesia: contested rights in Rempek Village, Lombok. Land Use Policy 57, 241-249. doi: 10.1016/j.landusepol.2016.06.002

Rights and Resources Initiative (2018). At a Crossroads: Trends in Recognition of Community-Based Forest Tenure from 2002-2017. Rights and Resources Initiative, Washington, DC. Available online at: https://rightsandresources.org/ en/publication/at-a-crossroadstrends-in-recognition-of-community-basedforest-tenure-from-2002-2017/

Robinson, B. E., Holland, M. B., and Naughton-Treves, L. (2014). Does secure land tenure save forests? A meta-analysis of the relationship between land tenure and tropical deforestation. Glob. Environ. Change Hum. Policy Dimens. 29, 281-293. doi: 10.1016/j.gloenvcha.2013. 05.012

Robinson, B. E., Masuda, Y. J., Kelly, A., Holland, M. B., Bedford, C., Childress, M., et al. (2018). Incorporating land tenure security into conservation. Conserv. Lett. 11:e12383. doi: 10.1111/conl.12383

Salk, C., Lopez, M. C., and Wong, G. (2017). Simple incentives and group dependence for successful payments for ecosystem services programs: evidence from an experimental game in Rural Lao PDR. Conserv. Lett. 10, 414-421. doi: $10.1111 /$ conl.12277

Scales, I. R. (2014). The future of conservation and development in Madagascar: time for a new paradigm? Madagascar Conserv. Dev. 9:8. doi: $10.4314 /$ mcd.v9i1.2

Schlager, E., and Ostrom, E. (1992). Property-rights regimes and natural resources: a conceptual analysis. Land Econ. 68, 249-262. doi: 10.2307/3146375 
Sims, K. R. E., and Alix-Garcia, J. M. (2017). Parks versus PES: evaluating direct and incentive-based land conservation in Mexico. J. Environ. Econ. Manage. 86, 8-28. doi: 10.1016/j.jeem.2016.11.010

Snilsveit, B., Stevenson, J., Langer, L., Tannous, N., Ravat, Z., Nduku, P., et al. (2019). Incentives for climate mitigation in the land use sector-the effects of payment for environmental services on environmental and socioeconomic outcomes in low- and middle-income countries: a mixed-methods systematic review. Campbell Syst. Rev. 15:e1045. doi: 10.1002/cl2.1045

Speelman, E. N., Rodela, R., Doddema, M., and Ligtenberg, A. (2019). Serious gaming as a tool to facilitate inclusive business; a review of untapped potential. Curr. Opin. Environ. Sustain. 41, 31-37. doi: 10.1016/j.cosust.2019.09.010

Styger, E., Rakotondramasy, H. M., Pfeffer, M. J., Fernandes, E. C. M., and Bates, D. M. (2007). Influence of slash-and-burn farming practices on fallow succession and land degradation in the rainforest region of Madagascar. Agric. Ecosyst. Environ. 119, 257-269. doi: 10.1016/j.agee.2006.07.012

Sunderlin, W. D., De Sassi, C., Sills, E. O., Duchelle, A. E., Larson, A. M., Resosudarmo, I., et al. (2018). Creating an appropriate tenure foundation for REDD+: the record to date and prospects for the future. World Dev. 106, 376-392. doi: 10.1016/j.worlddev.2018.01.010

Swallow, B., and Meinzen-Dick, R. (2009). "Payment for environmental services: interactions with property rights and collective action," in Institutions and Sustainability, eds V. Beckmann and M. Padmanabhan (Dordrecht: Springer), 243-265.

Travers, H., Clements, T., Keane, A., and Milner-Gulland, E. J. (2011). Incentives for cooperation: the effects of institutional controls on common pool resource extraction in Cambodia. Ecol. Econ. 71, 151-161. doi: 10.1016/j.ecolecon.2011.08.020

Unruh, J. D. (2008). Carbon sequestration in Africa: the land tenure problem. Glob. Environ. Change 18, 700-707. doi: 10.1016/j.gloenvcha.2008. 07.008

Urech, Z. L., Zaehringer, J. G., Rickenbach, O., Sorg, J.-P., and Felber, H. R. (2015). Understanding deforestation and forest fragmentation from a livelihood perspective. Madagascar Conserv. Dev. 10:10. doi: 10.4314/mcd. v10i2.5

Van Vliet, N., Mertz, O., Birch-Thomsen, T., and Schmook, B. (2013). Is there a continuing rationale for swidden cultivation in the 21st century? Hum. Ecol. 41, 1-5. doi: 10.1007/s10745-0139562-3

Van Vliet, N., Mertz, O., Heinimann, A., Langanke, T., Pascual, U., Schmook, B., et al. (2012). Trends, drivers and impacts of changes in swidden cultivation in tropical forest-agriculture frontiers: a global assessment. Glob. Environ. Change 22, 418-429. doi: 10.1016/j.gloenvcha.2011. 10.009
Vieilledent, G., Grinand, C., Rakotomalala, F. A., Ranaivosoa, R., Rakotoarijaona, J.-R., Allnutt, T. F., et al. (2018). Combining global tree cover loss data with historical national forest cover maps to look at six decades of deforestation and forest fragmentation in Madagascar. Biol. Conserv. 222, 189-197. doi: 10.1016/j.biocon.2018.04.008

Wilensky, U. (1999). NetLogo. Evanston, IL: Northwestern University. Available online at: http://ccl.northwestern.edu/netlogo/. CenterforConnectedLearningandComputer-BasedModeling

Witcomb, M., and Dorward, P. (2009). An assessment of the benefits and limitations of the shamba agroforestry system in Kenya and of management and policy requirements for its successful and sustainable reintroduction. Agrofor. Syst. 75, 261-274. doi: 10.1007/s10457-008-9200-z

Woolridge, J. (2010). Econometric Analysis of Cross Section and Panel Data Cambridge, 2nd Edn. MA: MIT University Press.

Wunder, S. (2015). Revisiting the concept of payments for environmental services. Ecol. Econ. 117, 234-243. doi: 10.1016/j.ecolecon.2014.08.016

Wunder, S., Börner, J., Ezzine-De-Blas, D., Feder, S., and Pagiola, S. (2020). Payments for environmental services: past performance and pending potentials. Ann. Rev. Resour. Econ. 12, 209-234. doi: 10.1146/annurev-resource-100518-094206

Zabel, F., Delzeit, R., Schneider, J. M., Seppelt, R., Mauser, W., and Václavík, T. (2019). Global impacts of future cropland expansion and intensification on agricultural markets and biodiversity. Nat. Commun. 10:2844. doi: 10.1038/s41467-019-10775-Z

Zaehringer, J. G., Eckert, S., and Messerli, P. (2015). Revealing regional deforestation dynamics in north-eastern madagascar-insights from multi-temporal land cover change analysis. Land 4, 454-474. doi: 10.3390/land4020454

Conflict of Interest: JR is the executive director of the association Madagasikara Voakajy which manages Mangabe protected area, one of our study areas.

The remaining authors declare that the research was conducted in the absence of any commercial or financial relationships that could be construed as a potential conflict of interest.

Copyright (C) 2021 Rakotonarivo, Bell, Dillon, Duthie, Kipchumba, Rasolofoson, Razafimanahaka and Bunnefeld. This is an open-access article distributed under the terms of the Creative Commons Attribution License (CC BY). The use, distribution or reproduction in other forums is permitted, provided the original author(s) and the copyright owner(s) are credited and that the original publication in this journal is cited, in accordance with accepted academic practice. No use, distribution or reproduction is permitted which does not comply with these terms. 